\title{
Advancement in Phosphoric Acid Doped Polybenzimidazole Membrane for High Temperature PEM Fuel Cells: A Review
}

\author{
A. A. Tahrim*, I. N. H. M. Amin \\ Section of Engineering Technology, Universiti Kuala Lumpur Malaysian Institute of \\ Chemical \& Biochemical Engineering Technology (UniKL MICET), 78000 Alor Gajah, \\ Melaka, Malaysia
}

Submitted: 21/9/2018. Revised edition: 5/11/2018. Accepted: 6/11/2018. Available online: 5/12/2018

\begin{abstract}
High-temperature polymer electrolyte membrane fuel cell as a sustainable green technology has been developed throughout the years as it provides several benefits compared to Nafion-based fuel cells (e.g., $\mathrm{CO}$ tolerance, improved kinetic and enhance water management). Polybenzimidazole which one of the best membrane candidates was extensively studied due to excellent properties to be used in hightemperature application. Impregnating polybenzimidazole with phosphoric acid are most commonly practised as an electrolyte membrane in the PEMFC. In this paper, recent advancement of the existing literature regarding work revolving polybenzimidazole to improve the performance of phosphoric acid doped polybenzimidazole membrane for high-temperature polymer electrolyte membrane fuel cell are reviewed. Notable works such as using aluminium containing silicate (Al-Si), silicon carbide whisker $(\mathrm{mSiC})$ and sulfonated graphene oxide in the composite PBI derivatives were observed. Proton conductivity are recorded at $0.371,0.271$ and $0.280 \mathrm{~S} / \mathrm{cm}$, respectively.
\end{abstract}

Keywords: Polybenzimidazole, high temperature membrane, proton conductivity, polymer electrolyte membrane fuel cell, cell performance

\subsection{INTRODUCTION}

The increase in the energy demands and the depletion of fossil fuels as sources of energy, a sustainable alternative energy sources are widely explored. With the concern to reduce the greenhouse emission as the by-product of using hydrocarbonbased energy source, a cleaner and environmentally friendly energy source a much more being preferred. Hydrogen energy-based system (polymer electrolyte membrane fuel cell) has been seen as a suitable candidate to provide energy since they do not emit pollutants such as $\mathrm{SO}_{\mathrm{x}}$, $\mathrm{NO}_{\mathrm{x}}$ and $\mathrm{CO}_{2}$ like hydrocarbon-based sources and highly efficient.

Generally, fuel cell can be classified based on their operating temperature, structure of the fuel but most commonly it is classified by the types of electrolytes used in the system [1].
1) Polymer Electrolyte Membrane Fuel Cell (PEMFC)

2) Alkaline Fuel Cell (AFC)

3) Phosphoric Acid Fuel Cell (PAFC)

4) Molten Carbonate Fuel Cell (MCFC)

5) Solid Oxide Fuel Cell (SOFC)

In the PEMFC system, energy is generated by the electrochemical reaction. Hydrogen (in form of pure gas, methanol or ethanol) are fed into the system as fuel at the anode. It will dissociate into protons and electrons. Protons will diffuse from anode to cathode through a membrane while electrons will travel to cathode by passing through external electric circuit. Protons, electrons and oxygen will react at the cathode and water are produced as a byproduct. Water is removed from the system by a flow of excess oxygen [2]. The flow of the PEMFC process are illustrated in Figure 
1 and the reaction at both side of electrode are as follows:

Anode: $\mathrm{H}_{2} \rightarrow 4 \mathrm{H}^{+}+4 e^{-}$

Cathode: $\mathrm{O}_{2}+4 \mathrm{H}^{+}+4 e^{-} \rightarrow 2 \mathrm{H}_{2} \mathrm{O}$

Overall: $2 \mathrm{H}_{2}+\mathrm{O}_{2} \rightarrow 2 \mathrm{H}_{2} \mathrm{O}$

A typical PEMFC and also direct methanol fuel cell (DMFC) used perfluorinated polymer membranes as the medium of proton carrier such as Nafion [3-5] which was developed DuPont.
Nafion has a polytetrafluoroethylene backbone which is similar to Teflon with the perflourinated chain linked together with ether bond and end with sulfonated group. The chemical structure of Nafion is in Figure 2. Apart from that, Dow, Asashi Galss Company (Flemion) and Asashi Chemical Company (Aciplex)[6] also successfully synthesised perfluorosulfonic acid membrane with a shorter side chain.

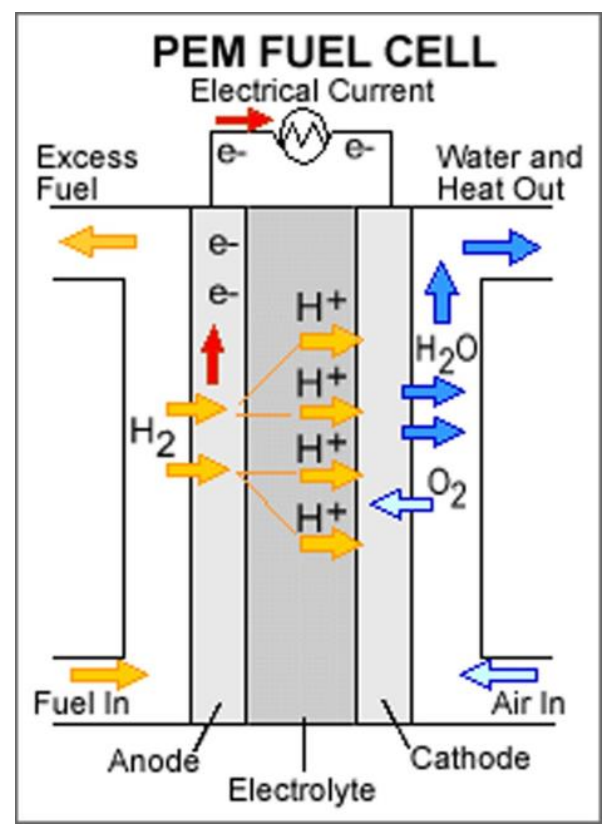

Figure 1 Schematic flow of PEMFC (Reprinted from "Hydrogen Fuel Cells" by J. K. Harbeck, 2010, Stanford University)

Nafion becomes a favour due to its high proton conductivity, good mechanical as well as commercial availabilities. However, it needs to be highlighted that proton conductivity in Nafion membrane are heavily relies upon hydration condition as water not only promoted the dissociation of proton from the sulfonic group but also contributed to highly mobile hydrated proton[7]. Nafion needs to be hydrated at the optimum level (proton conductivity of $0.1 \mathrm{~S} / \mathrm{cm}$ at $25-50 \%$ relative humidity, $(\mathrm{RH})$ $[8,9]$, all the times and in fuel cell system, a good humidifying system are required[10]. Despite have an outstanding performance,
PEMFC based on Nafion which are usually operated at low temperature environment $\left(<80{ }^{\circ} \mathrm{C}\right)$ faced several issues which can deteriorate its effectiveness. Among common issue which are constantly arise includes:

1. Catalyst poison: The presence of carbon monoxide $(\mathrm{CO})$ can affect the performance of membrane by occupying at the surface of platinum $(\mathrm{Pt})$ surface, blocking its active site and preventing the dissociation of hydrogen to protons and electrons [11]. Unrestrained concentration amount of $\mathrm{CO}(>10$ 
ppm) in the hydrogen $\left(\mathrm{H}_{2}\right)$ fuel can cause catalyst poison [12]. Since catalyst poison tends to be temperature dependent, operating PEMFC at the higher temperature could reduce the poison [13].

2. Water \& Heat Management: When operating PEMFC at temperature at $80{ }^{\circ} \mathrm{C}$, its efficiency can achieve approximately $40-50 \%$ and heat produced in the system need to be removed to maintain the operating temperature. Heat produced can be recovered as steam which can be reused for another application such as direct heating or steam reforming process. With this, the system overall efficiency will be increased [14]. PEMFC are operated at temperature between $70-80{ }^{\circ} \mathrm{C}$ with the intention to avoid the membrane degradation. When fuel cell operates below $60{ }^{\circ} \mathrm{C}$ can caused water condensation and flooding at the electrode eventually leads to voltage drop. These stringent thermal requirements present significant heat transport problems [15].

3. Electrode kinetics: Increased the operating temperature to fasten the reaction at the electrode (cathode; oxygen reduction reaction)[16].

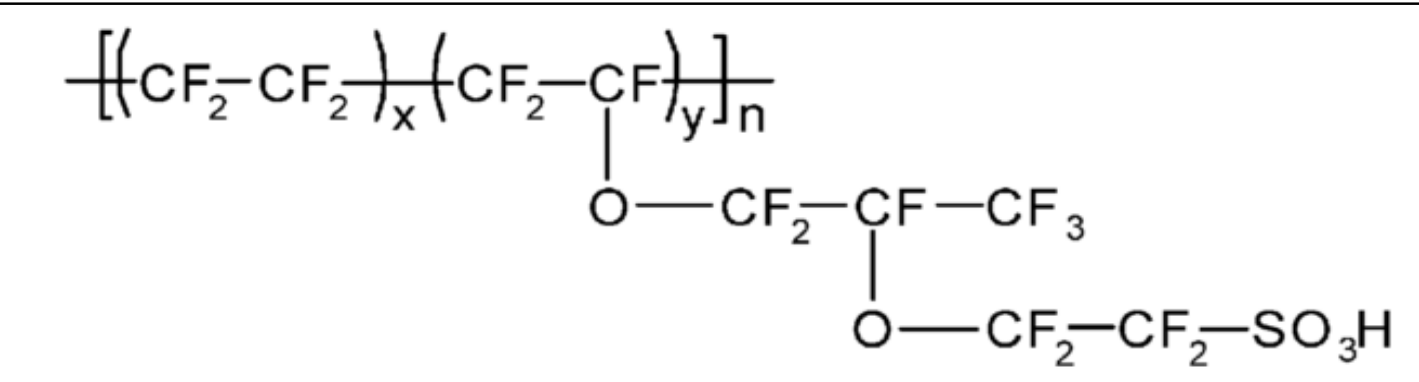

Figure 2 Chemical structure of Nafion

Realising the benefits operating PEMFC at higher temperature $\left(100-200^{\circ} \mathrm{C}\right)$, many works has been done along the line. As an alternative, non-fluorinated membranes apart of Nafion have been explored. Sulfonated membranes which are thermally stable such as poly(ether) sulfone (PES)[17]. Poly(ether ether) ketone (PEEK)[18], poly(ether ketone) (PEK)[19] and polyimides[20] are explored. In addition, polymers contain aromatic polyazoles are also being explored such as polybenzoxazoles

polybenzothiazoles (PBT)[22] and polybenzimidazole (PBI)[23].

Impressive progress has been and are being done to develop proton conducting membrane which being able to operate at temperature above $100^{\circ} \mathrm{C}$. Among the approaches, acid-base complex membrane such as phosphoric acid (PA) doped polybenzimidazole (PBI) polymers are getting attention. PA doped polybenzimidazole have excellent properties which allow them to operate at temperatures up to $200{ }^{\circ} \mathrm{C}$ without dehydration due to the presence of PA which acts as the proton carrier. Thus, in this paper, the aim is to update with existing literature review and also the current work revolving the polybenzimidazole as a polymer for the high-temperature PEMFC application.

\subsection{PROTON TRANSFER IN POLYBENZIMIDAZOLE MEMBRANE}

In general, proton transfer across the solid 
perfluorinated membrane usually follows by two mechanisms which are vehicle mechanism and Grotthus mechanism [24]. As for Nafion, proton transport mechanism conduction through the water. However, the proton does not travel as an isolated $\mathrm{H}+$. The presence of extra proton caused a proton defects which involved in a dimer or hydrated hydronium ion [9]. The proton defect migrates pass through the membrane which then act as a 'vehicle' for proton transport. Proton is dragged by the 'vehicle' which is $\mathrm{H}_{3} \mathrm{O}^{+}$as the water molecules pass through the membrane. Thus, it is essential for the membrane to stay hydrated.

As for acid doped polybenzimidazole membrane proton transfer mechanism conduction are through Grotthus mechanism [25,26]. Constant rearrangement in the proton environment enable proton to be transferred from one to the another with the aid of formation and breaking of hydrogen bonds (proton hopping)[25]. Figure 3 illustrated how proton hopping works in acid doped (Phosphoric acid) polybenzimidazole work. Due to the basic nature of benzimidazole ring $(\mathrm{pKa}=5.5)$ [27], polybenzimidazole can be doped with different type of acids.
Research show that under high concentration (11-16 $\mathrm{mol} / \mathrm{L})$, the performance of acid doped polybenzimidazole increased as follows [28]:

$$
\begin{gathered}
\mathrm{H}_{2} \mathrm{SO}_{4}>\mathrm{H}_{3} \mathrm{PO}_{4}>\mathrm{HCLO}_{4}>\mathrm{HNO}_{3} \\
>\mathrm{HCL}
\end{gathered}
$$

Sulfuric acid has been seen to have the best conductivity among other acids even compared with phosphoric acid[29]. However phosphoric acid is often used to doped polybenzimidazole since proton conductivity of sulfuric acid doped polybenzimidazole are dependent to humidity (relative humidity, $\mathrm{RH}$ ) to achieve high proton conductivity while phosphoric acid doped polybenzimidazole able to achieve proton conductivity of $7.9 \times 10^{-2} \mathrm{~S} / \mathrm{cm}\left(5 \% \mathrm{RH}\right.$ at $\left.200{ }^{\circ} \mathrm{C}\right)[30]$. Free acids were presence in the polymer along together with $\mathrm{H}_{2} \mathrm{PO}_{4}^{-} / \mathrm{HPO}_{4}^{2-}$ anionic chains increased the proton conductivity considerably. With mentioned acids above, the proton conductivity increases as the acid content increases [31].

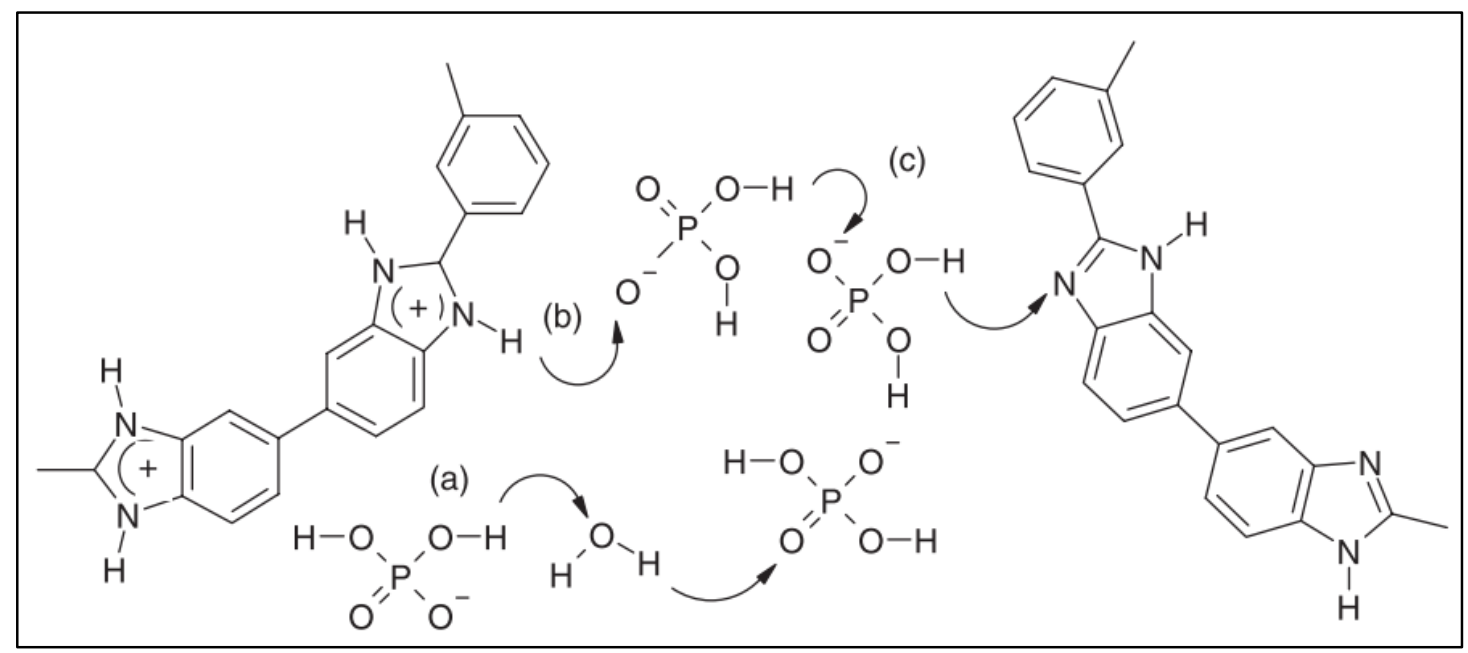

Figure 3 Proton transfer mechanism in Phosphoric Acid doped Polybenzimidazole. a) PA-Water proton transfer b) PBI -Water proton transfer c) PA-PA proton transfer. Reprinted from "Recent advances in Polybenzimidazole/phosphoric acid membrane for high temperature fuel cells" by S. Subianto, 2014, Polym Int;63:1134 - 1144. Adapted with permission 


\subsection{SYNTHESIS POLYBENZIMIDAZOLE}

OF

Polybenzimidazole (poly [2,2-(mphenylene)-5,5-bibenzimidazole]; $\mathrm{PBI}$ ) is an aromatic heterocyclic polymer which have a good thermal stability $\left(T_{g}=426-\right.$ $436{ }^{\circ} \mathrm{C}$ ), excellent chemical resistance and retention of toughness and stiffness. PBI are firstly discovered by melt condensation process of aromatic tetraamine with aromatic dicarboxylic acid with the presence of aromatic dibasic acid [32]. PBI can also by synthesis by solution polymerization where monomers are dissolved in a high polarity organic solvents such as $N, N$-dimethylacetamide (DMAc) and N-methyl-2-pyrrolidinone (NMP). However, a simpler method to synthesis polybenzimidazole are established by solution polymerization of diamines and carboxylic acids in polyphosphoric acid (PPA)[33,34]. PBI synthesis also can be handled by using methanesulfonic acid (PPMA)/phosphorus pentoxide $\left(\mathrm{P}_{2} \mathrm{O}_{5}\right)$ as a solvent [35].

Synthesis of polybenzimidazole using PPA produced a high molecular weight PBI polymer. PPA are used as polymerization medium and casting solvent [36]. Advantages of PPA process is that it uses moderate temperature $\left(180-200{ }^{\circ} \mathrm{C}\right)$ in a homogenous mixture. PPA is a good solvent for both monomers and polymer; where when mixed with monomers, mixed anhydrides are formed to activate the reaction. This PPA process allow simple preparation of polybenzimidazole polymer at a laboratory scale where only single stage solution polymerization is required. However, by using PPA process polymer produced often end up with a very diluted solution in PPA (3-5\%). In addition, by using PPA process polymer can be directly cast and PPA will be hydrolyze into PA as PPA are hygroscopic properties. Comparative study has been made between conventional casting (post membrane fabrication) direct casting method (in situ fabrication) via PPA and also between conventional imbibing process and sol-gel process [37,38]. Lee et al. recorded that $m$ PBI which are produced through direct casting method possess higher ionic conductivity $\left(0.12 \mathrm{~S} / \mathrm{cm}\right.$ at $\left.150{ }^{\circ} \mathrm{C}\right)$ compared to $m$-PBI which are produced using conventional casting method (0.08 $\mathrm{S} / \mathrm{cm}$ at $150{ }^{\circ} \mathrm{C}$. While Perry et al. found out that $m$-PBI which are produced through solgel demonstrated higher ionic conductivity than conventional imbibing process which is $0.17 \mathrm{~S} / \mathrm{cm}$ at $180{ }^{\circ} \mathrm{C}$ and $0.08 \mathrm{~S} / \mathrm{cm}$ at $180{ }^{\circ} \mathrm{C}$ respectively.

In most PBI polymer studies, commercially made available by Celanese corporation poly [2,2-(m-phenylene)-5,5bibenzimidazole or $m$-PBI (also known as PBI itself) were used. $\operatorname{Poly}(2,5-$ benzimidazole) (ABPBI) are also commonly used $[39,40]$ which have a maximum conductivity of $6.2 \times 10^{-2} \mathrm{~S} / \mathrm{cm}$ at $150{ }^{\circ} \mathrm{C}$ and $30 \%$ relative humidity. poly(2,2'-(1,4-phenylene) $5,5^{\prime}$ -

bibenzimidazole) (para-PBI or $p$-PBI) are also being successfully synthesised from 3,3',4,4'-Tetraaminobiphenyl (TAB) and tetraphthalic acid (TA) under PPA process have ionic conductivity of $0.24 \mathrm{~S} / \mathrm{cm}$ at 160 ${ }^{\circ} \mathrm{C}$ [41]. Other types of PBI polymer also has been successfully synthesized and explored which can be seen in Table 1 . Series of random copolymer of PBI has been composed and studied since the polymer architecture influence the properties of polymer. Ratio of sulfonated PBI and p-PBI type were controlled in the synthesis of random copolymer gel membrane. Optimum performance was reported at ratio $27 / 75$ of s-PBI/p-PBI copolymer which have a proton conductivity of $0.291 \mathrm{~S} / \mathrm{cm}$ at $160{ }^{\circ} \mathrm{C}$. By increasing the ratio of s-PBI in the copolymer, the performance of the membrane deteriorated [42].

Chemical modification of polybenzimidazole backbone were also being done to improve the performance of the polybenzimidazole. Addition of fluorine group towards the polybenzimidazole has demonstrated some 
promising result. In terms of processibility, oxidative stability [43].

fluorine containing PBI shows significant enhanced processability as well as

Table 1 Example of common derivatives of PBI membrane

Derivatives
Names

The presence of fluorine in the backbone structure of polybenzimidazole also aids in enhancing the ability to trap more phosphoric acid (PA) which resulting in increased in proton conductivity. However, the presence of imidazole group in the fluorine containing PBI need to be controlled to keep the mechanical properties and conductivity in balance. Increased in fluorine content reduced the mechanical stability as the fluorine decreased the intermolecular forces in the chain. On the other, the addition for fluorine improved the flexibility of the membrane. Fluorine containing PBI are reported to have a maximum conductivity of $0.0305 \mathrm{~S} / \mathrm{cm}$ at $150{ }^{\circ} \mathrm{C}$ with PA doping of 7 [50].

There several ways to improve the performance and properties by modifying the polybenzimidazole structure. Membrane durability of polybenzimidazole can be enhanced by crosslinking method or nanocomposite membrane to improve the proton conductivity of the membrane without reducing the mechanical properties of the polybenzimidazole membrane. Modification of polybenzimidazole also 
intends to prolong the life of the polymer for long time usability.

\subsection{PBI/INORGANIC COMPOSITE MEMBRANE TO ENHANCE PERFORMANCE}

In addressing limitation issue in phosphoric acid doped PBI membrane such as low mechanical properties caused by high doping level and acid leaching from the membrane in extreme temperature, one of the approaches that are widely used are incorporation of inorganic filler such as metal oxides $\left(\mathrm{TiO}_{2}, \mathrm{SiO}_{2}, \mathrm{SnO}_{2}\right)$ and carbon-based materials into polymeric membrane to form nanocomposite material. Devrim et al. [51] had prepared $\mathrm{PBI} / \mathrm{SiO}_{2}$ hybrid membrane which are tested in single cell HT-PEMFC exhibit higher proton conductivity compared to pristine $\mathrm{PBI}$ membrane which is $0.1027 \mathrm{~S} / \mathrm{cm}$ at $180{ }^{\circ} \mathrm{C}$ and $0.0944 \mathrm{~S} / \mathrm{cm}$ at $180{ }^{\circ} \mathrm{C}$ respectively. Comparative study also being done between different inorganic filler in the PBI nanocomposite membrane [52]. $\mathrm{TiO}_{2}, \mathrm{SiO}_{2}$ and $\mathrm{ZrP}$ has been added to investigate its performance in the nanocomposite PBI polymers. In addition, silica containing aluminium (Al-Si) was synthesised via solgel method and used as inorganic filler [53]. Although the nanocomposite membrane show superior performance in the proton conductivity compared to pristine PBI, polymer additives was suggested during the fabrication of nanocomposite membrane to avoid deterioration in mechanical properties due to particle agglomeration as the filler amount increased. Experimental study and composite membrane fabrication by using mixed metal oxide such as $\mathrm{Fe}_{2} \mathrm{TiO}_{5}$ has also being reported [54,55]. $\mathrm{Fe}_{2} \mathrm{TiO}_{5}$ is able to provide strong hydrogen bonding and increase the contents of the bound to free water into membrane matrix due to the presence- $\mathrm{OH}$ in the $\mathrm{Fe}_{2} \mathrm{TiO}_{5}$ [56]. Acid uptake test and proton conductivity at highest were observed when $4 \mathrm{wt} \%$ of $\mathrm{Fe}_{2} \mathrm{TiO}_{5}$ were used.
Perovskite type oxide such as strontium cerate $\left(\mathrm{SrCeO}_{3}\right)$ has the capabilities to conduct proton with the presence of water vapor and hydrogen. Due to the hygroscopic nature of $\mathrm{SrCeO}_{3}, \mathrm{PBI} /$ $\mathrm{SrCeO}_{3}$ nanocomposite membrane prepared by Shabinikia et al. exhibit higher proton conductivity to pristine PBIs which is $0.105 \mathrm{~S} / \mathrm{cm}$ at $180{ }^{\circ} \mathrm{C}$ and $0.046 \mathrm{~S} / \mathrm{cm}$ at $180{ }^{\circ} \mathrm{C}$ respectively [57]. Incorporation of $\mathrm{SrCeO}_{3}$ also help to retain more acid which is important that membrane to have a good acid retention to avoid the membrane from easily degrade.

Surface functionalised of inorganic filler in the fabrication of nanocomposite PBI are also being explored to further improve the performance of nanocomposite PBI membrane. Functionalised mesoporous silica (SBA-15) with different moieties such as acidic $\left(\mathrm{SO}_{3} \mathrm{H}^{-}\right)$, basic $\left(\mathrm{NH}_{2}{ }^{-}\right)$, and amphoteric $\left(\mathrm{SO}_{3} \mathrm{H}-\mathrm{NH}_{2}\right)$ are prepared to examine the influence in the electrochemical performance [58]. Apart from filler loading and functionalisation level that affect to the proton conductivity, modifying the surface of SBA-15 with acid or basic moieties such as amine and sulfonic group does not lead to increase in the proton conductivity. Amount of filler loading also influence the durability of phosphotungstic acid functionalized mesoporous silica/PBI composite membrane for long term usage[59]. Excessive addition of filler loading causing deterioration in the performance of the nanocomposite membrane as agglomeration were formed resulting in formation of pore and anisotropic structures. A low amount of filler $(2 \mathrm{wt} \%)$ in the $\mathrm{PBI} / \mathrm{TiO}_{2}$ nanocomposite are prepared and its behaviour in long term usage are being tested and excellent performance was observed[60].

Nawn et al. [61] and Nasef et al. [62] had both incorporated zirconium oxide $\left(\mathrm{ZrO}_{2}\right)$ to enhance the performance of PBI based nanocomposite membrane. Although different amount of filler loading that gives the different tensile strength, the addition of 
$\mathrm{ZrO}_{2}$ proved that the mechanical strength of nanocomposite increased with the presence of $\mathrm{ZrO}_{2}$. In a separate study, $\alpha$-zirconium phosphate was synthesis via separate nucleation and aging steps (SNAS) and used as inorganic compound to improve performance of nanocomposite PBI based membrane [63]. Quite recently, silicon carbide whisker ( $\mathrm{mSiC}$ ) were used to improve the membrane properties of nanocomposite PBI based membrane as it has excellent properties such as good thermal and electrochemical stability[64].

Apart from metal oxides, carbon nanotubes (CNTs) and heteropolyacids (HPAs) are also being used as inorganic filler. Due to the chemical structure of pure CNTs, it is common practice to modify the surface of multi-walled CNTs (MWCNTs) making them soluble in any organic solvent and to avoid inhomogeneous dispersion in polymer matrix due to aggregation. Among various functionalities that available; amine group, especially diamine group are favourable to be attached in the surface of MWCNTs [65]. Since diamine consists of two amino groups, one of them can be attach on MWCNTs while the other pair can be attached to any available groups. Under microscopic images, boundary between PBI and MWCNTs were not observed indicate well homogenous dispersion was obtained which leads to improve in the mechanical properties. MWCNTs are being treated by acid before titanium nanoparticles were grafted onto its surface to investigate its influence in the nanocomposite PBI based membrane [66]. On the other hand, Moreno et al. [67] addressed that surface functionalisation can cause disruption on structure of CNTs as $\mathrm{C}=\mathrm{C}$ bonds was broken down during the surface functionalisation resulting in declination of mechanical and electrical properties. Thus, PBI/CNT composite were prepared and improvement in the mechanical properties are observed for both undoped and doped nanocomposite as the tensile strength and Young's modulus were increased by $32 \%$ and $147 \%$ respectively.
Heteropolyacids (HPAs) such as 12silicotungstic acid, $\mathrm{H}_{4} \mathrm{SiW}_{12} \mathrm{O}_{4} \cdot 29 \mathrm{H}_{2} \mathrm{O}$ has successfully incorporated into PBI membrane without using $\mathrm{SiO}_{2}$ as a support [68]. After doping with PA, most of the HPA able to retain in the polymer matrix. Addition of HPAs was able to raise the proton conductivity by obstructing the water from escape out of the membrane at high temperature, reducing the dehydration of PA and also increase more acid site by providing extra help for proton transport. Another inorganic proton conducting solid, lithium hydrazinium sulfate $\left(\mathrm{LiN}_{2} \mathrm{H}_{5} \mathrm{SO}_{4}\right.$, $\mathrm{LiHzS}$ ) has been used in the nanocomposite PBI membrane [69]. Incorporation of $\mathrm{LiHzS}$ may have impact on proton conductivity, but it seems that the amount of $\mathrm{LiHzS}$ used must be kept at minimum level $(<5 \%)$ as it has no outstanding enhancement on proton conductivity when more LiHzS was used.

Another type of inorganic filler which gained attention among researcher recently are graphene oxide (GO) which are peeled off from graphite oxide nanoplatelets due to its notable mechanical properties, wide specific surface area and relatively cheap. Despite the favourable properties of GO, it is known that dispersion of the inorganic filler and compatibility between the composite membrane significantly affect the membrane properties. Thus, GO are often modified to overcome the mentioned problems. For example, triazole group has been introduced into GO with the aim to enhance the dispersion of $\mathrm{GO}$ in the polymer matrix as well as to improve proton conduction by formation of hydrogen bonding network with PA [70].

Proton conductivity of modified of GO with triazole was at $0.135 \mathrm{~S} \mathrm{~cm}^{-1}$ at $180{ }^{\circ} \mathrm{C}$ with tensile strength recorded at $12.6 \mathrm{MPa}$. Additionally, Cai et al. [71] prepared sulfonated $\mathrm{GO}$ was by radiation grafting through ${ }^{60} \mathrm{Co} \quad \gamma$-ray. Tensile strength, elongation break and tensile modulus performance were at peak when $1 \%$ of sulfonated GO before digression trend are seen as the amount of filler were increased 
which suggesting that sulfonated GO tends to agglomerate when in excess. Long term stability performance of $\mathrm{PBI} / \mathrm{GO}$ composite membrane were demonstrated which are prepared by solution casting method [72]. For over 500 hours testing, PBI/GO $2 \mathrm{wt} \%$ experienced $3.8 \%$ loss of membrane performance compared to pristine PBI membrane which experienced $9.3 \%$ loss. PBI/GO $2 \mathrm{wt} \%$ also exhibit the highest proton conductivity compared to prepared nanocomposite membrane and increase in amount of GO deteriorates the performance of nanocomposite as the nanocomposite become nonhomogeneous. A stack of graphene layer which are known as graphite nanoplates has introduced into PBI based polymer membrane [73]. Graphite nanoplates shows high electrical and thermal conductivity makes them interesting candidate in the composite material. Surprisingly, electrical conductivity was recorded at the highest which is at $480 \mathrm{~S} \mathrm{~cm}^{-1}$ at $45 \mathrm{wt} \%$ filler while the tensile strength is at peak (145.2 MPa) when $30 \%$ graphite nanoplates were used and indicates the filler was homogenously distributed in the polymer matrix. However, it is proposed that the composite membrane is suitable material for development of highly sensitive tensoresistors. While graphite oxide has been used and functionalised with ionic liquid groups such as 1-(3-aminopropyl)-3methylimidazolium bromide to form ionic liquid graphite oxide (ILGO) in the PBI/ILGO nanocomposite membrane which homogenous distribution in polymer matrices was observed by Xu et al. [74]

Speaking of ionic liquids (ILs), Hooshsyari et al. has focused on usage of dicationic ILs in the fabrication of nanocomposite PBI based membrane and its performance has been compared with monocationic ILs [75,76]. Dicationic ILs are group of ILs which comprises of a double charged cation that are composed of two charged cations linked by an alkyl chain connector and paired with two charged anions. Dicationic ILs possessed a high number of charge carrier which contributed to tridimensional network channel for proton transfer explained why $\mathrm{PBI} /$ dicationic ILs showed higher proton conductivity than PBI/monocationic ILs. Thermal properties of $\mathrm{PBI} /$ dicationic ILs are also enhanced compared to $\mathrm{PBI} /$ monocationic ILs and this might be associated with the liquid density of dicationic ILs that are higher than monocationic ILs. Bao et al. [77] has doped montmorillonite (MMT) sodium nanoclay with different ILs (1-Hexyl-3methylimidazoliumchloride ([HMIM]Cl) and 1,1,3,3-Tetramethylguanidine tetrafluoroborate ([TMG][BF4])) before incorporated into ABPBI polymer membrane to study its effect on the mechanical properties and ionic conductivity of the composite membrane.

Another inorganic filler that piqued researchers' interest in the fabrication of nanocomposite membrane is polyhedral oligomeric silsesquioxane (POSS). Embodied POSS in the nanocomposite are often done to enhance the mechanical and thermal stability due to filler effect. ABPBI has modified with Octa Ammonium POSS (AM-POSS) nanofiller via in situ polymerisation [78]. It was observed that ABPBI/AM-POSS showed more PA uptake which resulting in increase in proton conductivity of the nanocomposite membrane. Apart from the basic imidazole group which are present in the ABPBI, this observation is contributed by the amide groups which connects ABPBI and AMPOSS formed ionic bond with PA and hydrophilic nature of POSS can form hydrogen bond with PA. Another study was aimed to functionalise phosphonic group into iso-octylphenyl POSS/PBI without side reaction such as condensation of aggregation of phosphonic acid groups[79]. Although the objective of the study was achieved, and greater proton conductivity compared to pristine PBI was observed, solubility of the nanocomposite membrane significantly dropped. The summary of $\mathrm{PBI} /$ inorganic composite membrane are 
tabulated in Table 2.

\subsection{CROSSLINKING TO IMPROVE MEMBRANE DURABILITY}

By maximising the proton conductivity often resulting in the poor mechanical properties due to the plasticisation effect of PA. Thus, one of the common practises to improve the mechanical properties of any polymeric membrane include polybenzimidazole are crosslinking. Two main types of crosslinking which are ionic (between polymer blends or incorporation of inorganic material) and covalent crosslinking. Different in types of crosslinking do offer some advantages compared to other.

Acid-base polymer blends such as SPEEK/PBI [80] has been fabricated with the intention to improve the properties of the polymeric membrane. Prior to the fabrication of the polymer blend, SPEEK were transformed into SPEEK-Na by immersion into $\mathrm{NaOH}$ solution to avoid phase separation between SPEEK/PBI. Mechanical strength of the SPEEK/PBI blend improves as the content of PBI increase (56 MPa at $40 \%$ of $\mathrm{PBI}$ ) due to dense structure formed by acid-base interaction. Under Fenton Test's, SPEEK/PBI (40\%) shows only $8.21 \%$ weight loss showing that ionic crosslinked structure between hydrogen bonds between SPEEK and PBI polymer improves the oxidation stability. While previously, novel acid-base blend from polybenzimidazole derivatives such as $\mathrm{F}_{6} \mathrm{PBI}$, $\mathrm{PBIOO}$ and $\mathrm{PBI}$ HOZOL were crosslinked with several different acidic polymers where acid polymer component acts as macromolecules ionic cross linker [81]. By comparing to pure $\mathrm{PBI}$ and AB-PBI, mentioned acid-base blends show an improved weight loss during Fenton's Test. All acid -base blend used in the experiment shows less the $8 \%$ weight loss after 24 hours and less than $20 \mathrm{wt} \%$ after 144 hours in Fenton's Test while pure PBI membrane experiences almost $40 \mathrm{wt} \%$ weight loss under the same test.

Another approach was made which using epoxides as a crosslinking agent by forming covalent chain with the imidazole group that are available in the polybenzimidazole structure. To give a better understanding in the thermoplastic distortion of the acid doped $\mathrm{F}_{6} \mathrm{PBI}$ membrane, different epoxide which having different size with and without rigid groups of benzene ring were experimented [82]. Under thermogravimetric test, $\mathrm{F}_{6} \mathrm{PBI}$ which are crosslinked with rigid aromatic rings experienced less weight loss due to aromatic rings in the cross linker are much more stable compared to cross linker containing flexible alkyl structure. However, by using longer linear flexible chain cross linker a good mechanical property is observed (12.9 $\mathrm{MPa})$ although addition of crosslinking into $\mathrm{F}_{6} \mathrm{PBI}$ causes the membrane to become stiffer at normal condition but its mechanical structure was enhanced at elevated temperature. It is worth to take a note that increasing the amount of cross linker in the polymer would reduce the conductivity performance of the membrane $(0.033 \mathrm{~S} / \mathrm{cm}$ at $20 \% ; 0.06$ $\mathrm{S} / \mathrm{m}$ at $10 \%)$ as covalent crosslinking formed between the epoxide group of cross linkers and benzimidazole group would reduce the availability of free $-\mathrm{NH}_{2}$ that helps proton hopping. It is also suggested that the increment in the crosslinking degree causing more restricted polymer chain formed which hinder the proton conduction. Epoxide also being applied as a crosslinking agent in the PBI and ethyl phosphoric acid grafted PBI (PBI-EPA) polymer blend while investigating the performance of ethyl phosphoric acid grafted PBI in the polymer blend [83]. PBI with epoxide blend (PBI/EP) exhibit the highest maximum tensile stress among the blends (97.5 MPa), PBI/PBI-EPA/EP blends show superior properties in terms of PA doping level (approximately $430 \mathrm{wt} \%$ ) and proton conductivity $(0.081 \mathrm{~S} / \mathrm{cm}$ at 160 $\left.{ }^{\circ} \mathrm{C} \& 0 \% \mathrm{RH}\right)$ proving that addition of 
Table 2 Summary of composite membrane of polybenzimidszole derivatives

\begin{tabular}{|c|c|c|c|c|c|}
\hline Polymer & Inorganic Materials & $\begin{array}{c}\text { Loading } \\
\text { (wt\%) }\end{array}$ & Proton Conductivity $(\mathrm{S} / \mathrm{cm})$ and comments & Temperature $\left({ }^{\circ} \mathrm{C}\right)$ & Ref \\
\hline \multirow[t]{5}{*}{ PBI } & $\mathrm{SiO}_{2}$ & 5 & $0.1027 \mathrm{~S} / \mathrm{cm}$ & 180 & {$[51]$} \\
\hline & $\mathrm{TiO}_{2}, \mathrm{SiO}_{2} \& \mathrm{ZrP}$ & 5 & \begin{tabular}{|ll|}
\multicolumn{2}{|l|}{ Proton conductivity of: } \\
1) & $\mathrm{PBI} / \mathrm{SiO} 2: 0.133 \mathrm{~S} / \mathrm{cm}$ \\
2) & $\mathrm{PBI} / \mathrm{TiO} 2: 0.044 \mathrm{~S} / \mathrm{cm}$ \\
3) & $\mathrm{PBI} / \mathrm{ZrP}: 0.200 \mathrm{~S} / \mathrm{cm}$
\end{tabular} & 180 & {$[52]$} \\
\hline & $\mathrm{Al}-\mathrm{Si}$ & 12 & $0.31 \mathrm{~S} / \mathrm{cm}$ & 150 & {$[53]$} \\
\hline & $\mathrm{Fe}_{2} \mathrm{TiO}_{5}$ & 4 & $0.078 \mathrm{~S} / \mathrm{cm}$ & 180 & $\begin{array}{l}54, \\
55]\end{array}$ \\
\hline & $\mathrm{SrCeO}_{3}$ & 8 & $0.105 \mathrm{~S} / \mathrm{cm}$ & 180 & {$[57]$} \\
\hline $\begin{array}{l}\text { Poly-2,2'-(2,6- } \\
\text { pyridine)-5,5'- } \\
\text { bibenzimidazole }\end{array}$ & $\begin{array}{l}\text { SBA-15 with different } \\
\text { functional moieties. }\end{array}$ & & $\begin{array}{l}\text { Non-functionalised SBA-15 shows the highest } \\
\text { proton conductivity } 0.09 \mathrm{~S} / \mathrm{cm}\end{array}$ & 120 & {$[58]$} \\
\hline \multirow[t]{2}{*}{ PBI } & $\begin{array}{l}\text { Phosphotungstic acid } \\
\text { functionalized mesoporous } \\
\text { silica }\end{array}$ & 10 & $0.024 \mathrm{~S} / \mathrm{cm}$ & 200 & {$[59]$} \\
\hline & $\mathrm{TiO}_{2}$ & 2 & $\begin{array}{l}\text { Fuel cell stack with composite membrane } \\
\text { performed better compared with fuel cell stack } \\
\text { with tandard membrane at long time running }\end{array}$ & 150 & {$[60]$} \\
\hline $\begin{array}{l}\text { Poly[2,2'-(m- } \\
\text { phenylene)-5,5'- } \\
\text { bibenzimidazole] } \\
\text { (PBI-4N) } \\
\end{array}$ & $\mathrm{ZrO}_{2}$ & & $\begin{array}{l}0.104 \mathrm{~S} / \mathrm{cm} . \text { Author mentioned that addition } \\
\mathrm{ZrO}_{2} \text { acts as plasticizer in the nanocomposite } \\
\text { membrane. }\end{array}$ & 185 & {$[61]$} \\
\hline $\begin{array}{l}\text { 2,6-pyridine } \\
\text { polybenzimidazole } \\
(2,6-\mathrm{Py}-\mathrm{PBI})\end{array}$ & $\mathrm{ZrO}_{2}$ & 5 & $0.060 \mathrm{~S} / \mathrm{cm}$ & 150 & {$[62]$} \\
\hline OPBI & $\mathrm{mSiC}$ & & $0.271 \mathrm{~S} / \mathrm{cm}$ & 170 & {$[64]$} \\
\hline $\begin{array}{l}\text { PBI containing } \\
\text { triazole unit }\end{array}$ & MWCNTs & & - & & {$[65]$} \\
\hline
\end{tabular}




\begin{tabular}{|c|c|c|c|c|c|}
\hline Polymer & Inorganic Materials & $\begin{array}{c}\text { Loading } \\
\text { (wt\%) }\end{array}$ & Proton Conductivity $(\mathrm{S} / \mathrm{cm})$ and comments & Temperature $\left({ }^{\circ} \mathbf{C}\right)$ & Ref \\
\hline $\begin{array}{l}\text { Polybenzimidazole } \\
\text {-amide } \\
\text { (PBA)/sulfonated } \\
\text { polystyrene }\end{array}$ & $\begin{array}{l}\text { Titania nanoparticles grafted } \\
\text { MWCNTs }\end{array}$ & & $2.1 \mathrm{~S} / \mathrm{cm}$ & 80 & {$[66]$} \\
\hline \multirow[t]{6}{*}{ PBI } & CNTs & & $0.074 \mathrm{~s} / \mathrm{cm}$ & 180 & {$[67]$} \\
\hline & 12-Silicotungstic acid & 20 & $0.127 \mathrm{~S} / \mathrm{cm}$ & 160 & {$[68]$} \\
\hline & $\mathrm{LiHzS}$ & 5 & $0.021 \mathrm{~S} / \mathrm{cm}$ & 180 & {$[69]$} \\
\hline & Triazole modified GO & & $0.135 \mathrm{~S} / \mathrm{cm}$ & 180 & {$[70]$} \\
\hline & Sulfonated GO & 3 & $0.280 \mathrm{~S} / \mathrm{cm}$ & 170 & {$[71]$} \\
\hline & Graphene oxide & 2 & $0.1704 \mathrm{~S} / \mathrm{cm}$ & 180 & {$[72]$} \\
\hline OPBI & Graphene nanoplates (GNP) & 45 & $\begin{array}{l}480 \mathrm{~S} / \mathrm{cm} \text { (Used for development of highly } \\
\text { sensitive tensoresistors) }\end{array}$ & - & {$[73]$} \\
\hline \multirow[t]{2}{*}{ PBI } & $\begin{array}{l}\text { Ionic liquid graphite oxide } \\
\text { (ILGO) }\end{array}$ & & $0.035 \mathrm{~S} / \mathrm{cm}$ & 175 & {$[74]$} \\
\hline & Ionic liquids (ILs) & & $0.081 \mathrm{~S} / \mathrm{cm}$ & 180 & $\begin{array}{l}{[75,} \\
76]\end{array}$ \\
\hline Sulfonated ABPBI & $\begin{array}{l}\text { MMT sodium ionic liquids } \\
\text { mixture }\end{array}$ & 3 & $0.040 \mathrm{~S} / \mathrm{cm}$ & 220 & {$[77]$} \\
\hline ABPBI & $\begin{array}{l}\text { OctaAmmonium Polyhedral } \\
\text { oligosilsesquioxane (POSS) }\end{array}$ & & $>0.1 \mathrm{~S} / \mathrm{cm}$ & 160 & {$[78]$} \\
\hline OPBI & Phosphonic Acid - POSS & & $0.0028 \mathrm{~S} / \mathrm{cm}$ & 150 & {$[79]$} \\
\hline
\end{tabular}


crosslinking agent such as epoxide do enhance the mechanical properties of the polybenzimidazole.

Another simple method yet proved effective as a crosslinking agent are thermal treatment. Linear $m$-PBI polymer has been crosslinked through thermal curing to study the long-term durability of polybenzimidazole for the HT-PEMFC [84]. After 13,000 hours of constant operation, thermal crosslink linear $m$-PBI show lower degradation rate compared to linear $m$-PBI. Thermal crosslink $m$-PBI also show lesser acid loss as acid loss is a major degradation issue for long term operation. Joseph et al. [85] absorbed thermal crosslinking concept by blending sulfonated polysulfone (SPAES50) with commercially available PBI derivatives which is PBI-OO. With the intention to avoid $\mathrm{N}_{-} \mathrm{CH}_{2}$-links formed during the crosslinking; they are suggesting a new method to crosslink PBI which initially crosslinked the acid/base blend ionically before turns into covalently crosslinked the acid/base blend due to Friedel-Crafts reaction between sulfonic acid groups and electron rich phenyl groups after heated to above $200^{\circ} \mathrm{C}$. However, author did mention due to the low concentration of crosslinking groups are too low to be analysed by standard IR and can't be dissolved for high resolution solution sate NMR, the mechanism proposed cannot be verified in detail. Crosslinking PBI polymer via electron beam irradiation are also being considered by Lai et al. [86] A pilot study has been demonstrated to observe the enhancement on an ultra-thinned PBI membrane and as a result, mechanical stability was boosted as well as outstanding chemical and thermal stability were observed.

Addition of inorganic compound such as silane as a crosslinker has been practised with the aim to strengthen the PBI membrane through formation of siloxane network between the polymer. ((Chloromethyl)phenylethyl)trimethoxysil ane (Ph-Si) and 3- chloropropyltriethoxysilane (Pr-Si) which having rigid and non-rigid group of phenylene respectively, where grafted onto the backbone of PBI before crosslinked network were formed through hydrolysis process [87]. It was revealed that crosslinked membrane (PBI-Ph and PBIPr) exhibit higher weight loss than neat PBI during the Fenton's test although they possessed longer morphology durability. It was deduced that siloxane network easily degraded because of the attack of hydrogen peroxide or hydroxyl radical that protected the backbone of the PBI membrane. Overall, it may be said that addition of silane as a crosslinker had successfully reinforced the properties of PBI membrane in terms of membrane swelling, acid doping level and conductivity. However, a suitable chemical structure of silane as a crosslinker need to be chosen carefully as silane with a rigid structure offer a better performance than non-rigid or flexible structure. PBI-Ph (with rigid group of phenylene) showed higher acid doping levels, less swelling, higher conductivity, and improved mechanical strength, compared to crosslinked PBI-Pr (with non-rigid group of phenylene chain) and the neat PBI membranes. While Qian et al. group has incorporated siloxane network with the addition of phosphonic acid in polymer network [88]. Amino trimethylene phosphonic acid (ATMP) were functionalised with 3glycidoxypropyltrimethoxysilane

(GPTMS) before grafting onto the PBI backbone. All crosslinked PBI membrane show better mechanical strength due to the silane crosslinked structure but as for proton conductivity, and increasing amount of GPTMS in the network resulting in reduction of proton conductivity as less phosphonic acid in the membrane that helps for proton hopping. A polysiloxane phosphonic acid membrane were synthesised from epoxycyclohexylethyltrimethoxysilane (EHTMS) and amino trimethylene phosphonic acid (ATMP) was deemed as 
high proton conductivity under high temperature environment [89].

Crosslinking with PBI matrix was done to improve the mechanical properties and oxidative stability as it is too fragile. Increasing amount of PBI in the crosslinked polymer seems to have impact on the mechanical strength but as a trade-off proton conductivity are slightly reduced.

Due to the excellent properties of polybenzimidazole as a proton conducting material for PEMFC, some studies focused on introducing the groups into sulfonated polymer such as sulfonated polyimide (SPI) to form sulfonated poly(imide benzimidazole) or known as SPIBI. Pan et al.[90] and $\mathrm{Yu}$ et al. [91] had crosslinked SPIBI with 3,3', 5,5'tetramethyldiphenyldiglycidylether

(TMBP) and 4,4'-
bibromomethenyldiphenylether to form SPIBI-80 and CBrSPIBI respectively. Both crosslinked membranes are reported to have enhanced mechanical and chemical stability. However, degree of sulfonation (DS) and amount of crosslinker used in the membrane preparation influenced the properties of membrane such as mechanical, chemical stability and proton conductivity. Table 3 summarizes the effort of crosslinked PBI and its derivatives.

\subsection{NOVEL PA-DOPED POLYBENZIMIDAZOLE}

Numerous strategies have been taken up by researchers as discussed to elevate the membrane performance and it is undeniable that fruitful results were observed. Improvement in acid doping level (ADL) which subsequently increase the proton conductivity are often seen but on the other hand higher ADL means we jeopardised the mechanical stability which significantly reduces the membrane performance and durability. Thus, ADL and membrane stability issue were still a give and take situation in the HT-PEMFC and remained as a challenge. To address this matter, a novel PA-PBI membrane with excellent proton conductivity as well as mechanical stability was proposed. By introducing the flexible ether linkage (-O-) and phenyl group onto the backbone of PBI which was denoted as Ph-PBI, 'free volume' were formed in the 'sponge-like' structure were obtained due to side group with large steric will hindrance and causing the polymer chain to wrap and molecular chain packing density were reduced [92]. When comparing with poly[2,2'-(poxydiphenylene)-5,5'-bibenzimidazole]

(OPBI) which having a linear molecular structure, Ph-PBI exhibit ADLs 1.5 times higher than OPBI. Moreover, with the same ADLs, Ph-PBI showed 2-3 times lesser volume swelling. Due to the loose helical molecular chain and tendency to pack and form sponge-like structure, it is very appealing that even with the same ADLs, $\mathrm{Ph}-\mathrm{PBI}$ showed higher tensile strength than OPBI. Similarly, with the same approach flexible ether linkages and asymmetric bulky pendants phenyl and methylphenyl were introduced to form Me-PBI can comparative study between OPBI, Ph-PBI and Me-PBI were compared[93]. It was observed that both Me-PBI and Ph-PBI showed higher ADL but at the same time experienced lesser dimensional stability loss compared to OPBI. Thus, it shows that by revamping the PBI chain with suitable group can significantly improve the properties of PBI membrane. Ni et al. [94] had prepared a series of different degrees of hyperbranched PBI as alternative approach to enhance the ADL of PBI membrane. Increase in degree of hyperbranched PBI resulting in increased in ADL (1.8 times higher than OPBI) and higher proton conductivity (2.4 times greater than OPBI). However, increased in degree of branching causing the mechanical strength to deteriorate due to the entanglement and interaction between the polymer. PA which act as a plasticiser also contributed to the reduction in the mechanical strength. 
Table 3 Summary of crosslinked PBI derivatives membrane

\begin{tabular}{|c|c|c|c|c|c|c|}
\hline Polybenzimidazole & Crosslinked Material & $\begin{array}{c}\text { Type of } \\
\text { crosslinking }\end{array}$ & $\begin{array}{c}\text { Proton } \\
\text { Conductivity } \\
(\mathbf{S} / \mathbf{c m})\end{array}$ & $\begin{array}{l}\text { Temperature } \\
\left({ }^{\circ} \mathrm{C}\right)\end{array}$ & $\begin{array}{l}\text { Relative } \\
\text { Humidity } \\
\text { (RH) (\%) }\end{array}$ & Ref \\
\hline PBI & Sulfonated Poly(ether ether ketone) (SPEEK) & Ionic & 0.1985 & 170 & 100 & {$[80]$} \\
\hline $\mathrm{F}_{6} \mathrm{PBI}$ & $\begin{array}{l}\text { Series of epoxides: } \\
\text { 1) Bisphenol A diglycidyl ether (R1) } \\
\text { 2) Bisphenol A propoxylate diglycidyl } \\
\text { ether (R2) } \\
\text { 3) Poly(ethylene glycol) diglycidyl ether } \\
\text { (R3) }\end{array}$ & Covalent & 0.060 & 160 & 0 & [82] \\
\hline PBI & ethyl phosphoric acid-grafted PBI (PBI-EPA) & Covalent & 0.081 & 160 & 0 & [83] \\
\hline$m$-PBI & $m$-PBI & Thermal & - & 160 & 0 & [84] \\
\hline PBI-OO & $\begin{array}{l}\text { Sulfonated poly(arylene ether } \\
\text { sulfone) (SPAES50) }\end{array}$ & Thermal & - & 160 & 0 & [85] \\
\hline Ultra-thin PBI & - & $\begin{array}{l}\text { Electron } \\
\text { beam } \\
\text { irradiation }\end{array}$ & - & 160 & 0 & [86] \\
\hline \multirow[t]{3}{*}{ PBI } & $\begin{array}{l}\text { ((Chloromethyl)phenylethyl)trimethoxysila e } \\
\text { (Ph-Si) and 3- chloropropyltriethoxysilane (Pr- } \\
\text { Si) }\end{array}$ & Covalent & 0.13 & 180 & 0 & [87] \\
\hline & Phosphonic acid functionalized siloxane & Covalent & 0.031 & 160 & 0 & [88] \\
\hline & Polysiloxane phosphonic acid & Covalent & 0.034 & 140 & 0 & [89] \\
\hline $\begin{array}{l}\text { Sulfonated poly(imide } \\
\text { benzimidazole) (SPIBI) }\end{array}$ & $\begin{array}{l}\text { 3,3',5,5'tetramethyldiphenyldiglycidyl ether } \\
\text { (TMBP) }\end{array}$ & Thermal & 0.021 & 150 & 0 & [90] \\
\hline SPIBI & 4,4'-bibromomethenyl diphenyl ether & Covalent & 0.042 & 130 & 30 & [91] \\
\hline
\end{tabular}


On the hand, solubility issue of PBI in organic solvent was highlighted and by introducing flexible segment into PBI improved the dissolution of PBI. A novel PBI were synthesised by introducing pyridine and ether groups into PBI backbone in the phosphorous pentoxide/methanesulfonic acid (PPMA) as a solvent [95]. Ether group will aid in enhancing the polymer solubility and flexibly while pyridine was added to increase the number of density site for acid doping which eventually improve the proton conductivity. Pyridine containing PBI (PDA-PBI) have excellent solubility in methanesulfonic acid (MSA), sulfuric acid $\left(\mathrm{H}_{2} \mathrm{SO}_{4}\right)$, dimethyl sulfoxide (DMSO), NMethyl-2-pyrrolidone (NMP) and in dimethylformamide (DMF) and dimethylacetamide (DMAc) required help from heating. However, PDA-PBI insoluble in tetrahydrofuran (THF), toluene and chloroform even at high temperature while commercial PBI dissolved in aprotic solvent such as $\mathrm{DMAc} / \mathrm{LiCl}$ at elevated temperature. Decrease in rigidity of polymer by addition of ether linkages and protonation effect at the nitrogen atom in the pyridine ring with some polar solvent improve the solubility of the PBI polymer. With the improvement in the dissolution of PDA-PBI, polymer can be easily cast via solution casting method with DMSO, DMA or DMF as solvent. The proton conductivity PDA-PDI were reported at $0.083 \mathrm{~S} / \mathrm{cm}$ at $160^{\circ} \mathrm{C}$. With the aim of producing new PBI polymer which having a good processability, the usage of bulky constituent in the PBI structure such as bulky bromide, phenyl and trifluoromethyl substituted phenyl substituent were grafting onto the PBI structure.

Different sets of experiments were conducted by changing the structure of tetraamines[96] and diacids [97] before PBI polymerisation with mentioned bulky constituent. The solubility of the prepared membrane was much better compared to PBI which are not modified with bulky constituent and summarised in Table 4.

Table 4 Solubility of bulky constituent containing PBI membranes

\begin{tabular}{|c|c|c|c|c|c|c|c|}
\hline \multicolumn{7}{|c|}{$\begin{array}{c}\text { PBI containing bulky } \\
\text { constituent }\end{array}$} & \multicolumn{7}{|c|}{ Solvent } \\
\hline Tetraamine & Diacids & DMAc & DMF & NMP & DMSO & MSA & H2So4 \\
\hline P1 & & +- & - & +- & - & ++ & ++ \\
\hline P2 & & ++ & + & +++ & ++ & +++ & +++ \\
\hline P3 & & ++ & +- & ++ & - & ++ & ++ \\
\hline & P4 & + & + & ++ & - & ++ & ++ \\
\hline & P5 & + & + & + & + & ++ & ++ \\
\hline & P6 & + & + & ++ & - & ++ & ++ \\
\hline
\end{tabular}

P1 Bromide

P2 Phenyl

P3 Trifluoromethyl substituted phenyl substituents

P4 Bromide

P5 Phenyl

P6 Trifluoromethyl- substituted phenyl substituents

+++ : soluble at room temperature; ++ : soluble at $60{ }^{\circ} \mathrm{C} ;+$ : soluble at $80{ }^{\circ} \mathrm{C} ;+-$ : soluble at $100{ }^{\circ} \mathrm{C} ;-$ : partially soluble at $100^{\circ} \mathrm{C} ;--$ : insoluble at $100^{\circ} \mathrm{C}$

Reprinted from "Polybenzimidazoles containing bulky substituents and ether linkages for hightemperature proton exchange membrane fuel cell applications", by Chen J, Chen P, Liu Y, Chen K. J Memb Sci 2016;513:270-9 and "Synthesis of soluble polybenzimidazoles for hightemperature proton exchange membrane fuel cell ( PEMFC ) applications" by Chen J, Chen P, Lee S, Liou G, Chen C, Lan Y, et al. React Funtional Polym 2016. Adapted with permisssion. 
Alteration using bulky constituent whether at the tetraamine or the diacids, do have additional impact on the properties of the PBI membrane. When the structure of tetraamine were altered by bulky constituent (P1 - P3), ADL for P2 (phenyl substituents) at the highest which are explained by the extra availability of free volume for PA molecules while lower ADL are seen for P3 due to hydrophobic behaviour of trifluoromethyl groups. When modified PBI membranes were evaluated for oxidative stability, P3 show superior performance as hydrophobic behaviour of trifluoromethyl obstructing the path of aqueous oxidants (hydrogen peroxide) into the membrane. As for bulky constituent containing diacids (P4-P6) in the PBI fabrication, it was found that all PBIs didn't exhibit satisfied mechanical properties compared to $m$-PBI. It was deducted that that these kinds of pattern are caused by the loose inter-chain packing and less interaction caused from the addition of ether linkage and bulky substituent. However, PA doped P4- P6 are strong enough for MEA fabrication. Due to the loose inter-chain packing which resulting to more free space for proton transportation which explain how can P6 exhibit highest proton conductivity $(0.053 \mathrm{~S} / \mathrm{cm})$ with lesser PA uptake compared to others.

\subsection{COPOLYMER BLOCK OF POLYBENZIMIDAZOLE}

One of the main parameters for the PEMFCs membrane is the durability as PBI is a fully aromatic heterocyclic polymer, contain reactive sites of electron rich and easily raided by oxidants such as $\mathrm{HO}$ and $\mathrm{HO}_{2}$ radicals. To tackle this issue, sulfide units containing monomer were introduced into copolymer of PBI to act as an antioxidant and to improve the solubility and possibility properties[98]. Radical are often produced during the transfer of electron process and it can initiate chain reaction and harmful to the fuel cell. Sulfide are acted as antioxidant by removing free radical intermediates which resulting in terminating the chain reactions. Another approach to eliminate the radical is by introducing bipyridine unit into backbone of PBI copolymer [99]. It was proposed that the chain reaction was eliminated when free radical intermediates were removed by the nitrogen atoms of the bipyridine, retarding the oxidation reaction preventing it from attacking the $\mathrm{N}-\mathrm{H}$ of imidazole groups. It is also observed that addition of bipyridine monomer enhanced the solubility of copolymer making it easier to process compared to meta-PBI or ABPBI.

While still focusing to improve the solubility of PBI especially ABPBI, Yuan et al. [100] had used phenoxyl compound in the diaminobenzoic acid to copolymerized with diaminobenzoic acid under microwave irradiation to speed up the reaction. When the phenoxyl content were increased, copolymer show better solubility in organic solvent such as DMAc and DMF. The presence of ether linkage in the phenoxyl contributed to the changes in polymer rigidity and interaction of hydrogen bonding between the copolymer backbones.

A series of block copolymers which consist of "phosphophilic" PBI and "phosphophobic" non PBI segment were synthesised and studied [101]. With the intention to keep the non-PBI at constant length, the length of PBI segment are varied to enhance the proton conductivity of the copolymer membrane. In addition to expand the literature of structure-property relationship of non-PBI segment, different chemical structure of non-PBI segment were changed and studied. Improved balanced properties such as PA doping level and ionic conductivity are observed with the selective of block copolymers structure and segment's length. However, an additional treatment is required during the MEA fabrication to improve the electrochemical characteristic before 
satisfied performance were obtained as block copolymer performed poorly at the beginning.

\subsection{OTHER DOPED POLYBENZIMIDAZOLES}

Numerous methods have been applied to improve the proton conductivity of PBI membrane. PA doped PBI membrane seems to be the best candidate for temperature PEMFC due to it exhibit high proton conductivity under high temperature and low humidity. Unfortunately, PA doped PBI experienced acid leaching which deteriorates its performance. As an alternative, water insoluble proton conductor such as metal sulfophenyl phosphates (MSPP, M= Zr, $\mathrm{Ce}$ and $\mathrm{Fe}$ ) were used as a dopant for PBI membrane for high temperature PEMFC application. Cerium sulfophenyl phosphate (CeSPP) has been used to doped PBI membrane and proton conductivity seems to be improved even at different RH [102]. However, excess CeSPP seems to reduce the mechanical strength of the membrane.

A couple of studies has been conducted using Ferric sulfophenyl phosphate (FeSPP) as a dopant in the composite membrane of glass fiber (GF)/PBI [103] and pre-oxidized acrylic fiber (POAF)/PBI[104]. Fibers were incorporated to $\mathrm{PBI}$ to increase the mechanical properties of the membrane while FeSPP were used with the intention to improve the proton conductivity to address the trade-off of the proton conductivity and mechanical stability issue. GF/PBI/FeSPP shows an improved membrane property such as tensile strength and swelling ratio but proton conductivity was slightly reduced compared to PBI/FeSPP. Similar trend also can be seen when POAF were used. POAF/PBI/FeSPP seems able to reduce swelling ratio by half and improved mechanical strength but slightly reduction in the proton conductivity were seen compared to
PBI/FeSPP.

\subsection{CONCLUSION}

Various approaches have been conducted and studied to solve the hurdles face by phosphoric acid doped polybenzimidazole for high temperature polymer electrolyte membrane fuel cell application. Either it is to improve the oxidative stability, durability or processability of the membrane, they are still room for improvement to make polybenzimidazole still the best candidate for fuel cell operation which can replace Nafion especially for high temperature application. Careful selection of the material used should be considered to ensure polybenzimidazole can meet the commercialize standard and can still be consider as relatively cheap. With the most recent studies are focused on to improve the physical and chemical properties of the membrane itself, perhaps additional studies can be focus on the other component of the MEA such as usage of platinum catalyst loading to make sure the production cost can stay relevant.

Within this paper, recent efforts on the advancement on improvement of the phosphoric acid doped polybenzimidazole are reviewed. Hybrid materials are developed either through crosslinking methods, modification of polybenzimodazole structure or addition of inorganic proton conducting materials were used to achieve research objectives which the results are significant. Different types of simple or complex blends were fabricated and able to accomplish desirable results.

\section{REFERENCES}

[1] I. EG\&G Technical Services. 2004. Fuel Cell Handbook. Fuel Cell. 7 Edition: 1-352.

[2] S. Authayanun, K. Im-orb, and A. Arpornwichanop. 2015. A Review of 
the Development of High Temperature Proton Exchange Membrane Fuel Cells. Chinese $J$. Catal. 36: 473-483.

[3] K.-D. Kreuer, ed. Fuel Cell: Selected Entries from the Encyclopedia of Sustainability Science and Technology, 2013.

[4] S. M. J. Zaidi, and T. Matsuura. 2009. Polymer Membranes for Fuel Cells. Fuel Cells. Springer.

[5] A. Hamnett. 2010. The Components of an Electrochemical Cell. Handbook of Fuel Cells.

[6] V. Neburchilov, J. Martin, H. Wang, and J. Zhang. 2007. A Review of Polymer Electrolyte Membranes for Direct Methanol Fuel Cells. J. Power Sources. 169: 221-238.

[7] C. Yang, P. Costamagna, S. Srinivasan, J. Benziger, and A. B. Bocarsly. 2001. Approaches and Technical Challenges to High Temperature Operation of Proton Exchange Membrane Fuel Cells. Journal of Power Sources. 103: 1-9

[8] M. F. Mathias, R. Makharia, H. a. Gasteiger, J. J. Conley, T. J. Fuller, C. J. Gittleman, S. S. Kocha, D. P. Miller, C. K. Mittelsteadt, T. Xie, S. G. Yan, and P. T. Yu. 2005. Two Fuel Cell Cars in Every Garage? Electrochem. Soc. Interface. 14: 2435.

[9] S. Bose, T. Kuila, T. X. H. Nguyen, N. H. Kim, K. Lau, and J. H. Lee. 2011. Polymer Membranes for High Temperature Proton Exchange Membrane Fuel Cell: Recent Advances and Challenges. Prog. Polym. Sci. 36: 813-843.

[10] P. Sridhar, R. Perumal, N. Rajalakshmi, M. Raja, and K. S. Dhathathreyan. 2001. Humidification Studies on Polymer Electrolyte Membrane Fuel Cell. J. Power Sources. 101: 72-78.

[11] J. J. Baschuk, and X. Li. 2001. Carbon Monoxide Poisoning of Proton Exchange Membrane Fuel
Cells. Int. J. Energy Res. 25: 695-713.

[12] P. Krishnan, J.-S. Park, and C.-S. Kim. 2006. Performance of a Poly(2,5-benzimidazole) Membrane Based High Temperature PEM Fuel Cell in the Presence Of Carbon Monoxide. J. Power Sources. 159: 817-823.

[13] X. Gang. 1995. Hydrogen Oxidation on Gas Diffusion Electrodes for Phosphoric Acid Fuel Cells in the Presence of Carbon Monoxide and Oxygen. J. Electrochem. Soc. 142: 2890.

[14] Q. Li, R. He, J. O. Jensen, and N. J. Bjerrum. 2003. Approaches and Recent Development of Polymer Electrolyte Membranes for Fuel Cells Operating above $100{ }^{\circ} \mathrm{C}$. Chem. Mater. 15: 4896-4915.

[15] S. G. Kandlikar, and Z. Lu. 2009. Thermal Management Issues in a PEMFC Stack - A Brief Review of Current Status. Appl. Therm. Eng. 29: 1276-1280.

[16] J. A. Asensio, E. M. Sánchez, and P. Gómez-Romero. 2010. Protonconducting Membranes Based on Benzimidazole Polymers for HighTemperature PEM Fuel Cells. A Chemical Quest. Chem. Soc. Rev. 39: 3210-3239.

[17] L. Li, and Y. Wang. 2005. Sulfonated Polyethersulfone Cardo Membranes for Direct Methanol Fuel Cell. $J$. Memb. Sci. 246: 167-172.

[18] A. Iulianelli, and A. Basile. 2012. Sulfonated PEEK-based Polymers in PEMFC and DMFC Applications: A Review. Int. J. Hydrogen Energy. 37: 15241-15255.

[19] B. Liu, G. P. Robertson, D. S. Kim, M. D. Guiver, W. Hu, and Z. Jiang. 2007. Aromatic Poly(ether ketone)s with Pendant Sulfonic Acid Phenyl Groups Prepared by a Mild Sulfonation Method for Proton Exchange Membranes. Macromolecules. 40: 1934-1944.

[20] S. Chen, Y. Yin, H. Kita, and K. I. 
Okamoto. 2007. Synthesis and Properties of Sulfonated Polyimides from Homologous Sulfonated Diamines Bearing bis(aminophenoxyphenyl) Sulfone. $J$. Polym. Sci. Part A Polym. Chem. 45: 2797-2811.

[21] D. Zhao, J. Li, M. K. Song, B. Yi, H. Zhang, and M. Liu. 2011. A Durable Alternative for Proton-exchange Membranes: Sulfonated Poly(benzoxazole thioether sulfone)s. Adv. Energy Mater. 1: 203-211.

[22] J. a Osaheni, and S. a Jenekhe. 1992. Synthesis and Processing of Heterocyclic Polymers as Materials . 1. New Conjugated Rigid-Rod Benzobisthiazole Polymers. Chem. Mater. 11: 1282-1290.

[23] J. Zhang, Y. Tang, C. Song, and J. Zhang. 2007. Polybenzimidazolemembrane-based PEM Fuel Cell in the Temperature Range of 120$200{ }^{\circ}$ C. J. Power Sources. 172: 163171.

[24] G. Hoogers. 2002. Fuel Cell Technology Handbook. CRC Press Bool.

[25] Y.-L. Ma, J. S. Wainright, M. H. Litt, and R. F. Savinell. 2004. Conductivity of PBI Membranes for High-Temperature Polymer Electrolyte Fuel Cells. J. Electrochem. Soc. 151: A8.

[26] Z. Zuo, Y. Fu, and A. Manthiram. 2012. Novel Blend Membranes Based on Acid-base Interactions for Fuel Cells. Polymers (Basel). 4: 1627-1644.

[27] J. T. Wang, R. F. Savinell, J. Wainright, M. Litt, and H. Yu. 1996. A H2/O2 Fuel Cell Using Acid Doped Polybenzimidazole as Polymer Electrolyte. Electrochim. Acta. 41: 193-197.

[28] B. Xing, and O. Savadogo. 1999. The Effect of Acid Doping on the Conductivity of Polybenzimidazole (PBI). J. New Mater. Electrochem. Syst. 2: 95-101.
[29] O. Savadogo, and B. Xing. 2000. Hydrogen/oxygen Polymer Electrolyte Membrane Fuel Cell (PEMFC) based on Acid-doped polybenzimidazole (PBI). J. New Mater. Electrochem. Syst. 3: 343-347.

[30] R. He, Q. Li, G. Xiao, and N.J. Bjerrum. 2003. Proton Conductivity of Phosphoric Acid Doped Polybenzimidazole and Its Composites with Inorganic Proton Conductors. J. Memb. Sci. 226: 169184.

[31] D. J. Jones, and J. Rozière. 2001. Recent Advances in the Functionalisation of Polybenzimidazole and Polyetherketone for Fuel Cell Applications. J. Memb. Sci. 185: 4158.

[32] H. Vogel, and C. S. Marvel. 1961. Polybenzimidazoles, New Thermally Stable Polymers. J. Polym. Sci. 50: 511-539.

[33] Y. Iwakura, K. Uno, and Y. Imai. 1964. Polyphenylenebenzimidazoles. J. Polym. Sci. Part A-1 Polym. Chem. 2: 2605-2615.

[34] N. Yoda, and M. Kurihara. 1971. New Polymers of Aromatic Heterocycles by Polyphosphoric Acid Solution Methods. J. Polym. Sci. 109-193.

[35] M. Ueda, and H. Sugita. 1989. Poly(benzimidazole) Synthesis by Direct Reaction of Methoxyphthalic Acids And Tetramine. J. Polym. Sci. Part A Polym. Chem. 27: 2815-2818.

[36] K. Fishel, G. Qian, and B.C. Benicewicz. 2016. PBI Membranes via the PPA Process. Q. Li, D. Aili, H. A. Hjuler, J. O. Jensen (Eds.). High Temp. Polym. Electrolyte Membr. Fuel Cells; Approachs, Status Perspect. Springer Science Business Media, LLC. 217-238.

[37] J. W. Lee, D. Y. Lee, H. J. Kim, S. Y. Nam, J. J. Choi, J. Y. Kim, J. H. Jang, E. Cho, S. K. Kim, S. A. Hong, and T. H. Lim. 2010. Synthesis and 
Characterization of Acid-doped Polybenzimidazole Membranes by Sol-gel and Post-membrane Casting Method. J. Memb. Sci. 357: 130-133.

[38] K. A. Perry, K. L. More, E. Andrew Payzant, R. a. Meisner, B. G. Sumpter, and B. C. Benicewicz. 2014. A Comparative Study of Phosphoric Acid-doped $m$-PBI Membranes. $J$. Polym. Sci. Part B Polym. Phys. 52: 26-35.

[39] J. A. Asensio, S. Borrós, and P. Gómez-Romero. 2004. Polymer Electrolyte Fuel Cells Based on Phosphoric Acid-Impregnated Poly(2,5-benzimidazole) Membranes. J. Electrochem. Soc. 151: A304.

[40] J.A. Asensio, S. Borrós, and P. Gómez-Romero. 2004. Protonconducting Membranes based on Poly(2,5-benzimidazole) (ABPBI) and phosphoric Acid Prepared by Direct Acid Casting. J. Memb. Sci. 241: 89-93.

[41] S. Yu, H. Zhang, L. Xiao, E.-W. Choe, and B.C. Benicewicz. 2009. Synthesis of Poly (2,2'-(1,4phenylene) 5,5'-bibenzimidazole) ( para -PBI) and Phosphoric Acid Doped Membrane for Fuel Cells. Fuel Cells. 9: 318-324.

[42] J. A. Mader, and B. C. Benicewicz. 2011. Synthesis and Properties of Random Copolymers of Functionalised Polybenzimidazoles for High Temperature Fuel Cells. Fuel Cells. 11: 212-221.

[43] S.-W. Chuang, S.L.-C. Hsu, and M.L. Yang. 2008. Preparation and Characterization of FluorineContaining

Polybenzimidazole/imidazole Hybrid Membranes for Proton Exchange Membrane Fuel Cells. Eur. Polym. J. 44: 2202-2206.

[44] T. H. Kim, T. W. Lim, and J. C. Lee. 2007. High-temperature Fuel Cell Membranes based on Mechanically Stable Para-ordered Polybenzimidazole Prepared by
Direct Casting. J. Power Sources. 172: 172-179.

[45] H. J. Kim, S. Y. Cho, S. J. An, Y. C. Eun, J. Y. Kim, H. K. Yoon, H. J. Kweon, and K. H. Yew. 2004. Synthesis of poly(2,5-benzimidazole) for Use as a Fuel-cell Membrane. Macromol. Rapid Commun. 25: 894897.

[46] A. Sannigrahi, G. Sandip, J. Lalnuntluanga, and T. Jana. 2009. How the Monomer Concentration of Polymerization Influences Various Properties of Polybenzimidazole: A Case Study with $\operatorname{Poly}(4,40-$ diphenylether-5,50-

bibenzimidazole). J. Appl. Polym. Sci. 111: 1763-1772.

[47] G. Qian, and B. C. Benicewicz. 2009. Synthesis and Characterization of High Molecular Weight Hexafluoroisopropylidene-

Containing Polybenzimidazole for High-temperature Polymer Electrolyte Membrane Fuel Cells. $J$. Polym. Sci. Part A Polym. Chem. 47: 4064-4073.

[48] S. W. Chuang, and S. L. C. Hsu. 2006. Synthesis and Properties of a New Fluorine-containing

Polybenzimidazole for HighTemperature Fuel-cell Applications. J. Polym. Sci. Part A Polym. Chem. 44: 4508-4513.

[49] J. Peron, E. Ruiz, D. J. Jones, and J. Rozière. 2008. Solution Sulfonation of a Novel Polybenzimidazole. A Proton Electrolyte for Fuel Cell Application. J. Memb. Sci. 314: 247256.

[50] H. Pu, L. Wang, H. Pan, and D. Wan. 2010. Synthesis and Characterization of Fluorine-containing Polybenzimidazole for Proton Conducting Membranes in Fuel Cells. J. Polym. Sci. Part A Polym. Chem. 48: 2115-2122.

[51] Y. Devrim, H. Devrim, and I. Eroglu. 2016. Polybenzimidazole/SiO2 Hybrid Membranes for High 
Temperature Proton Exchange Membrane Fuel Cells. Int. J. Hydrogen Energy. 41: 10044-10052.

[52] Y. Özdemir, N. Üregen, and Y. Devrim. 2016. Polybenzimidazole based Nanocomposite Membranes with Enhanced Proton Conductivity For High Temperature PEM Fuel Cells. Int. J. Hydrogen Energy. 1-10.

[53] K. Seo, J. Seo, K.-H. Nam, and H. Han. 2017.

Polybenzimidazole/inorganic

Composite Membrane with Advanced Performance for High Temperature Polymer Electrolyte Membrane Fuel Cells. Polym. Compos. 38: 87-95.

[54] M. Moradi, A. Moheb, M. Javanbakht, and K. Hooshyari. 2016. Experimental Study and Modeling of Proton Conductivity of Phosphoric Acid Doped PBI-Fe2TiO5 Nanocomposite Membranes for Using in High Temperature Proton Exchange Membrane Fuel Cell (HTPEMFC). Int. J. Hydrogen Energy. 41: 2896-2910.

[55] A. Shabanikia, M. Javanbakht, H. S. Amoli, K. Hooshyari, and $\mathrm{M}$. Enhessari. $2015 . \quad$ Novel Nanocomposite Membranes based on Polybenzimidazole and Fe2TiO5 Nanoparticles for Proton Exchange Membrane Fuel cells. Ionics (Kiel). 21: 2227-2236.

[56] P. Christian, F. der Kammer, M. Baalousha, and T. Hofmann. 2008. Nanoparticles: Structure, Properties, Preparation and Behaviour in Environmental Media. Ecotoxicology. 17: 326-343.

[57] A. Shabanikia, M. Javanbakht, H. S. Amoli, K. Hooshyari, and M. Enhessari. 2015. Polybenzimidazole/strontium Cerate Nanocomposites with Enhanced Proton Conductivity for Proton Exchange Membrane Fuel Cells Operating at High Temperature. Electrochim. Acta. 154: 370-378.
[58] S. Angioni, D. C. Villa, A. S. Cattaneo, P. Mustarelli, and E. Quartarone. 2015. Influence of Variously Functionalized SBA-15 fillers on Conductivity and Electrochemical Properties of PBI Composite Membranes for High Temperature Polymer Fuel Cells. $J$. Power Sources. 294: 347-353.

[59] D. Aili, J. Zhang, M. T. Dalsgaard Jakobsen, H. Zhu, T. Yang, J. Liu, M. Forsyth, C. Pan, J.O. Jensen, L. N. Cleemann, S. P. Jiang, and Q. Li. 2016. Exceptional Durability Enhancement of PA/PBI based Polymer Electrolyte Membrane Fuel Cells for High Temperature Operation at $200^{\circ}$ C. J. Mater. Chem. A. 4: 4019-4024.

[60] F. J. Pinar, P. Cañizares, M. A. Rodrigo, D. Úbeda, and J. Lobato. 2015. Long-term Testing of a HighTemperature Proton Exchange Membrane Fuel Cell Short Stack Operated with Improved Polybenzimidazole-based Composite Membranes. J. Power Sources. 274: 177-185.

[61] G. Nawn, G. Pace, S. Lavina, K. Vezz, E. Negro, F. Bertasi, S. Polizzi, and V. Di Noto. 2015. Nanocomposite Membranes based on Polybenzimidazole and $\mathrm{ZrO} 2$ for High-Temperature Proton Exchange Membrane Fuel Cells. ChemSusChem. 8: 1381-1393.

[62] M. M. Nasef, T. Fujigaya, E. Abouzari-Lotf, N. Nakashima, and Z. Yang. 2016. Enhancement of Performance of Pyridine Modified Polybenzimidazole Fuel Cell Membranes Using Zirconium Oxide Nanoclusters and Optimized Phosphoric Acid Doping Level. Int. J. Hydrogen Energy. 41: 6842-6854.

[63] Q. Zhang, H. Liu, X. Li, R. Xu, J. Zhong, R. Chen, and X. Gu. 2016. Synthesis and Characterization of Polybenzimidazole/ $\alpha$-zirconium Phosphate Composites as Proton 
Exchange Membrane. Polym. Eng. Sci. 56: 622-628.

[64] Y. Cai, Z. Yue, Q. Jiang, and S. Xu. 2017. Modified Silicon Carbide Whisker Reinforced Polybenzimidazole Used for High Temperature Proton Exchange Membrane. J. Energy Chem. 27(3): 820-825.

[65] A. Zadehnazari, and M. A. Takassi. 2016. Synthesis of Modified Multiwalled Carbon Nanotube Poly(Benzimidazole-imide)

Composites: Assessment of Morphological and ThermoMechanical Properties. Journal Composite Interfaces. 23(9): 909-924.

[66] A. Kausar. 2015. Proton Exchange Fuel Cell Membranes of Poly(benzimidazoleamide)/sulfonated polystyrene/titania nanoparticles- Grafted-multi-walled Carbon Nanotubes. J. Plast. Film Sheeting. 31: 27-44.

[67] N. Guerrero Moreno, D. Gervasio, A. Godínez García, and J.F. Pérez Robles. 2015. Polybenzimidazolemultiwall Carbon Nanotubes Composite Membranes for Polymer Electrolyte Membrane Fuel Cells. $J$. Power Sources. 300: 229-237.

[68] V. T. Nguyen, J. T. Ziolo, Y. Yang, D. Diercks, S. M. Alfaro, H. A. Hjuler, T. Steenberg, and A. M. Herring. 2017. 12-Silicotungstic Acid Doped Phosphoric Acid Imbibed Polybenzimidazole for Enhanced Protonic Conductivity for High Temperature Fuel Cell Applications. J. Electrochem. Soc. 164: F504-F513.

[69] J. W. Jung, S. K. Kim, and J. C. Lee. 2010. Preparation of Polybenzimidazole/lithium hydrazinium Sulfate Composite Membranes for High-temperature Fuel Cell Applications. Macromol. Chem. Phys. 211: 1322-1329.

[70] J. Yang, C. Liu, L. Gao, J. Wang, Y. $\mathrm{Xu}$, and $\mathrm{R}$. He. 2015. Novel
Composite Membranes of Triazole Modified Graphene Oxide and Polybenzimidazole for High Temperature Polymer Electrolyte Membrane Fuel Cell Applications. RSC Adv. 5: 101049-101054.

[71] Y. Cai, Z. Yue, and S. Xu. 2017. A Novel Polybenzimidazole Composite Modified by Sulfonated Graphene Oxide for High Temperature Proton Exchange Membrane Fuel Cells In Anhydrous Atmosphere. J. Appl. Polym. Sci. 44986: 1-8.

[72] N. Üregen, K. Pehlivanoğlu, Y. Özdemir, and Y. Devrim. 2016. Development of Polybenzimidazole/graphene Oxide Composite Membranes for High Temperature $\{\mathrm{PEM}\}$ Fuel Cells. Int. J. Hydrogen Energy. 42(4): 26362647.

[73] B. C. Kholkhoev, E. N. Gorenskaya, S. A. Bal'zhinov, I. A. Farion, G. N. Batorova, A. V. Nomoev, P. S. Timashev, B. R. Radnaev, R. K. Chailakhyan, V. E. Fedorov, and V. F. Burdukovskii. 2016. Functional Composites based on Polybenzimidazole and Graphite Nanoplates. Russ. J. Appl. Chem. 89: 780-786.

[74] C. Xu, X. Liu, J. Cheng, and K. Scott. 2015. A Polybenzimidazole/ionicliquid-graphite-oxide Composite Membrane for High Temperature Polymer Electrolyte Membrane Fuel Cells. J. Power Sources. 274: 922927.

[75] K. Hooshyari, M. Javanbakht, and M. Adibi. 2016. Novel Composite Membranes Based on PBI and Dicationic Ionic Liquids for High Temperature Polymer Electrolyte Membrane Fuel Cells. Electrochim. Acta. 205: 142-152.

[76] K. Hooshyari, M. Javanbakht, and M. Adibi. 2016. Novel Composite Membranes based on Dicationic Ionic Liquid and Polybenzimidazole Mixtures as Strategy for Enhancing 
Thermal and Electrochemical Properties of Proton Exchange Membrane Fuel Cells Applications At High Temperature. Int. J. Hydrogen Energy. 41: 10870-10883.

[77] X. Bao, F. Zhang, and Q. Liu. 2015. Sulfonated Poly(2,5-benzimidazole) (ABPBI)/ MMT/ Ionic Liquids Composite Membranes for High Temperature PEM Applications. Int. J. Hydrogen Energy. 40: 1676716774.

[78] Q. Liu, Q. Sun, N. Ni, F. Luo, R. Zhang, S. Hu, X. Bao, F. Zhang, F. Zhao, and X. Li. 2016. Novel Octopus Shaped Organic - Inorganic Composite Membranes for PEMFCs. Int. J. Hydrogen Energy. 41: 1616016166.

[79] S. K. Kim. 2016. Polybenzimidazole and Phosphonic Acid Groupsfunctionalized Polyhedral Oligomeric Silsesquioxane Composite Electrolyte for High Temperature Proton Exchange Membrane. J. Nanomater. 2016: 2954147.

[80] M. Song, X. Lu, Z. Li, G. Liu, X. Yin, and Y. Wang. 2016. Compatible Ionic Crosslinking Composite Membranes based on SPEEK and PBI for High Temperature Proton Exchange Membranes. Int. J. Hydrogen Energy. 41: 12069-12081.

[81] F. Mack, K. Aniol, C. Ellwein, J. Kerres, and R. Zeis. 2015. Novel Phosphoric Acid-doped PBI-blends as Membranes for High-temperature PEM Fuel Cells. J. Mater. Chem. A. 3: 10864-10874.

[82] J. Yang, Y. Xu, P. Liu, L. Gao, Q. Che, and R. He. 2015. Epoxides Cross-linked Hexafluoropropylidene Polybenzimidazole Membranes for Application as High Temperature Proton Exchange Membranes. Electrochim. Acta. 160: 281-287.

[83] P. Ngamsantivongsa, H. L. Lin, and T. L. Yu. 2016. Crosslinked Ethyl Phosphoric Acid Grafted
Polybenzimidazole and Polybenzimidazole Blend Membranes for High-temperature Proton Exchange Membrane Fuel Cells. J. Polym. Res. 23: 1-11.

[84] T. Søndergaard, L. N. Cleemann, H. Becker, D. Aili, T. Steenberg, H. A. Hjuler, L. Seerup, Q. Li, and J. O. Jensen. 2017. Long-term Durability of HT-PEM Fuel Cells based on Thermally Cross-linked Polybenzimidazole. J. Power Sources. 342: 570-578.

[85] D. Joseph, N. N. Krishnan, D. Henkensmeier, J. H. Jang, S. H. Choi, H.-J. Kim, J. Han, and S. W. Nam. 2017. Thermal Crosslinking of $\mathrm{PBI} /$ sulfonated Polysulfone based Blend Membranes. J. Mater. Chem. A. 5: 409-417.

[86] S. Lai, J. Park, S. Cho, M. Tsai, H. Lim, and K. Chen. 2016. Mechanical Property Enhancement of Ultra-thin PBI Membrane by Electron Beam Irradiation for PEM Fuel Cell. Int. $J$. Hydrogen Energy. 41: 9556-9562.

[87] J. Yang, L. Gao, J. Wang, Y. Xu, C. Liu, and R. He. 2017. Strengthening Phosphoric Acid Doped Polybenzimidazole Membranes with Siloxane Networks for Using as High Temperature Proton Exchange Membranes. Macromol. Chem. Phys. 218(10).

[88] W. Qian, C. Shen, S. Gao, and J. Xiang. 2017. Phosphonic Acid Functionalized Siloxane Crosslinked with $3-$ glycidoxyproyltrimethoxysilane Grafted Polybenzimidazole High Temperature Proton Exchange Membranes. J. Appl. Polym. Sci. 134: 1-10.

[89] H. Li, C. Shen, S. Yin, and W. Li. 2016. Preparation of Polysiloxane Phosphonic Acid Doped Polybenzimidazole Hightemperature Proton-exchange Membrane. J. Appl. Polym. Sci. 133: 6-11. 
[90] H. Pan, S. Chen, Y. Zhang, M. Jin, Z. Chang, and H. Pu. 2015. Preparation and Properties of the Cross-linked Sulfonated Polyimide Containing Benzimidazole as Electrolyte Membranes in Fuel Cells. J. Memb. Sci. 476: 87-94.

[91] Z. Yue, Y. Ben Cai, and S. Xu. 2016. Phosphoric Acid-doped Cross-linked Sulfonated Poly(imidebenzimidazole) for Proton Exchange Membrane Fuel Cell Applications. $J$. Memb. Sci. 501: 220-227.

[92] X. Li, H. Ma, H. Wang, S. Zhang, Z. Jiang, B. Liu, and M. D. Guiver. 2015. Novel PA-doped Polybenzimidazole Membranes with High Doping Level, High Proton Conductivity and High Stability for HT-PEMFCs. RSC $A d v$. 5: 53870-53873.

[93] X. Li, H. Ma, Y. Shen, W. Hu, Z. Jiang, B. Liu, and M. D. Guiver. 2016. Dimensionally-stable Phosphoric Acid-doped Polybenzimidazoles for High-temperature Proton Exchange Membrane Fuel Cells. J. Power Sources. 336: 391-400.

[94] J. Ni, M. Hu, D. Liu, H. Xie, X. Xiang, and L. Wang. 2016. Synthesis and Properties of Highly Branched Polybenzimidazoles as Proton Exchange Membranes for HighTemperature Fuel Cells. J. Mater. Chem. C. 4: 4814-4821.

[95] J. Fang, X. Lin, D. Cai, N. He, and J. Zhao. 2016. Preparation and Characterization of Novel Pyridinecontaining Polybenzimidazole Membrane for High Temperature Proton Exchange Membrane Fuel Cells. J. Memb. Sci. 502: 29-36.

[96] J. Chen, P. Chen, Y. Liu, and K. Chen. $2016 . \quad$ Polybenzimidazoles Containing Bulky Substituents and Ether Linkages for High-temperature Proton Exchange Membrane Fuel Cell Applications. J. Memb. Sci. 513: 270-279.

[97] J. Chen, P. Chen, S. Lee, G. Liou, C. Chen, Y. Lan, and K. Chen. 2016.
Synthesis of Soluble Polybenzimidazoles for Hightemperature Proton Exchange Membrane Fuel Cell (PEMFC) Applications. React. Funtional Polym. 108: 122-129.

[98] C. He, K. F. Han, J. H. Yu, H. Zhu, and Z. M. Wang. 2016. Novel Antioxidative Membranes based on Sulfide-containing

Polybenzimidazole for High Temperature Proton Exchange Membrane Fuel Cells. Eur. Polym. J. 74: 168-179.

[99] G. Sun, K. Han, J. Yu, H. Zhu, and Z. Wang. 2016. Non-planar Backbone Structure Polybenzimidazole Membranes with Excellent Solubility, High Proton Conductivity, and Better Anti-oxidative for HT-PEMFCs. RSC Adv. 6: 91068-91076.

[100] Q. Yuan, G. H. Sun, K. F. Han, J. H. Yu, H. Zhu, and Z. M. Wang. 2016. Copolymerization of 4-(3,4-diaminophenoxy)-benzoic Acid and 3,4diaminobenzoic Acid Towards H3PO4-doped PBI Membranes for Proton Conductor with Better Processability. Eur. Polym. J. 85: 175-186.

[101]F. Schönberger, G. Qian, and B. C. Benicewicz. 2017. Polybenzimidazole-based Block Copolymers: From Monomers to Membrane Electrode Assemblies for High Temperature Polymer Electrolyte Membrane Fuel Cells. $J$. Polym. Sci. Part A Polym. Chem. 55: 1831-1843.

[102] P. Sun, Z. Li, F. Dong, S. Wang, X. Yin, and Y. Wang. 2017. High Temperature Proton Exchange Membranes based on Cerium Sulfophenyl Phosphate Doped Polybenzimidazole by End-group Protection and Hot-pressing Method. Int. J. Hydrogen Energy. 42: 486-495. [103] P. Sun, Z. Li, L. Jin, S. Wang, and X. Yin. 2017. Construction of Proton Channels and Reinforcement of 
Physicochemical Properties of oPBI/FeSPP/GF High Temperature PEM via Building Hydrogen Bonding Network. Int. J. Hydrogen Energy. 42: 14572-14582.

[104] P. Sun, Z. Li, L. Jin, Y. Yang, S. Wang, X. Yin, and Y. Wang. 2017. Pre-Oxidized Acrylic Fiber
Reinforced Ferric Sulfophenyl Phosphate-doped

Polybenzimidazole-Based Hightemperature Proton Exchange Membrane. Macromol. Mater. Eng. 201600468: 1600468. 